\title{
KEPUTUSAN FIKTIF SEBAGAI DASAR PENGAJUAN GUGATAN SENGKETA TATA USAHA NEGARA
}

\author{
I Gede Buonsu, A.A Sagung Laksmi Dewi, Luh Putu Suryani \\ Fakultas Hukum, Universitas Warmadewa, Denpasar-Bali, Indonesia \\ gedebuonsu@gmail.com, Laksmidewi.fhwjurnal@gmail.com, Suryani.fhwjurnal@gmail.com
}

\begin{abstract}
Abstrak
Berdasarkan pengertian sengketa tata usaha negara dapat dilihat bahwa suatu sengketa Tata Usaha Negara memiliki objek berupa KTUN, yang telah diatur dalam Pasal 1 ayat (9) Undang-Undang Nomor 51 Tahun 2009. KTUN sendiri dapat dibagi menjadi dua yaitu KTUN fiktif negatif dan positif yang diatur dalam pasal 3 UU PTUN dan pasal 53 UU Administrasi Pemerintahan. Penelitian ini bertujuan untuk menganalisis pengaturan keputusan TUN fiktif menurut hukum positif di Indonesia dan mengetahui keputusan TUN fiktif sebagai obyek sengketa TUN. Penelitian ini menggunakan metode penelitian deskriptif normative dengan pendekatan hukum, konseptual dan kasus. Hasil penelitian menunjukan bahwa keputusan TUN fiktif dapat dibagi menjadi dua yaitu TUN fiktif negatif dan KTUN fiktif positif yang dimana kedua aturan tersebut secara tidak langsung menimbulkan konflik dikarenakan sama-sama mengatur tentang TUN fiktif namun memiliki pemaknaan yang berbeda, dimana berdasarkan pasal 3 dimaknai sebagai keputusan penolakan (KTUN fiktif negatif) sedangkan menurut ketentuan pasal 53 dimaknai sebagai keputusan pengabulan (KTUN fiktif positif).
\end{abstract}

Kata Kunci: Keputusan fiktif, sengketa, obyek sengketa

\begin{abstract}
Based on the definition of a state administrative dispute, it can be seen that a State Administrative Dispute has an object in the form of a State Administrative Court, which has been regulated in Article 1 paragraph (9) of Law Number 51 of 2009. State Administrative Court itself can be divided into two, namely negative and positive fictional KTUN regulated in article 3 of the Administrative Court Law and article 53 of the Government Administration Law. This study aims to analyze the arrangement of fictitious TUN decisions according to positive law in Indonesia and to find out the fictional TUN decisions as objects of state administration disputes. This research uses descriptive normative research methods with legal, conceptual and case approaches. The results showed that the decision of fictitious TUN can be divided into two, namely negative fictitious TUN and positive fictitious TUN in which the two rules indirectly cause conflict because they both regulate fictitious TUN but have different meanings, where based on Article 3 is interpreted as a decision rejection (negative fictitious KTUN) while according to the provisions of Article 53 it is interpreted as a decision to grant (positive fictitious KTUN). Keywords: fictitious decision, lawsuit, lawsuit object
\end{abstract}

\section{PENDAHULUAN}

Hukum merupakan kumpulan peraturan yang terdiri dari berbagai norma dan sanksi-sanksi. Hukum bertujuan untuk menciptakan suatu keadaan yang tertib dalam pergaulan manusia, sehingga dapat memelihara keamanan. Menurut Dirdjosisworo (2010) tujuan hukum adalah melindungi individu dalam hubungannya dengan masyarakat, sehingga dapat diharapkan terwujudnya keadaan aman, tertib dan adil (Daliyo, 1989). Sebagai negara Hukum Pancasila yang dianut oleh Negara Indonesia, maka dalam penyelenggaraan kehidupan maupun pemerintahan haruslah didasarkan pada Pancasila. Hal ini merupakan salah satu dari ciri khas konsep negara hukum Pancasila karena diangkat dari nilai-nilai yang telah lama ada di Indonesia.

Dari penjelasan di atas dapat disimpulkan bahwa segala tindakan, kebijakan dan masalah yang dihadapi harus diselesaikan dengan hukum. Dalam hal ini sebagai pembahasan dalam penelitian ini menganalisis tentang sengketa Tata Usaha Negara. Berdasarkan pengertian sengketa tata usaha negara dapat dilihat bahwa suatu sengketa tata usaha negara memiliki objek berupa KTUN, yang telah diatur didalam Pasal 1 ayat (9) Undang-Undang Nomor 51 Tahun 2009 yang menyebutkan bahwa KTUN merupakan penetapan tertulis yang dikeluarkan oleh badan atau pejabat TUN yang berisikan tindakan hukum TUN yang berdasarkan peraturan yang berlaku serta bersifat konkret, individual, dan final sehingga menimbulkan akibat hukum bagi seseorang dan badan hukum. 
Di sisi lain, bentuk pengajuan atas sikap diam badan atau pejabat pemerintahan sebagaimana disebut dengan KTUN fiktif positif dan KTUN fiktif negatif memiliki bentuk yang berbeda ketika akan diajukan ke Pengadilan. Berdasarkan ketentuan Pasal 53 ayat (1) Undang-Undang Nomor 9 Tahun 2004 tentang Perubahan Kedua atas UU PTUN menyebutkan bahwa KTUN fiktif negatif dapat diajukan dengan bentuk gugatan sedangkan berdasarkan Peraturan Mahkamah Agung Nomor 5 Tahun 2015 menyatakan bahwa pengajuan KTUN fiktif positif adalah melalui bentuk permohonan. Dengan demikian pertentangan norma yang terjadi berdampak terhadap ketidakpastian hukum atau keraguraguan dalam penerapannya.

Beberapa penelitian serupa juga pernah dikaji oleh peneliti lain yang memiliki rumusan dan hasil penelitian yang berbeda dengan penelitian sekarang ini, salah satunya yaitu mengenai pengujian keputusan fiktif positif di pengadilan tata usaha negara (Wulandari, 2020), selanjutnya penelitian lain mengenai konsep fiktif positif dalam penerapannya di pengadilan tata usaha negara (Ahmad, 2017), dan terakhir mengenai problematika penyelesaian perkara fiktif positif di pengadilan tata usaha negara (Heriyanto, 2019). Berdasarkan uraian di atas, maka penelitian baru ini bertujuan untuk menganalisis Pengaturan Keputusan TUN fiktif menurut hukum positif di Indonesia dan menganalisis keputusan TUN fiktif sebagai obyek sengketa TUN.

\section{METODE PENELITIAN}

Dalam penelitian ini, peneliti menggunakan tipe penelitian hukum normatif. Penelitian hukum normatif juga disebutkan sebagai suatu penelitian terhadap kaidah atau norma hukumnya dalam peraturan perundang-undangan, yurisprudensi maupun hukum yang tidak tertulis. Sedangkan penulis menggunakan pendekatan perundang-undangan (statute approach), pendekatan konseptual (conceptual approach) dan pendekatan kasus (case approach) (Marzuki, 2010).

Sumber Bahan hukum dalam penelitian ini, terdapat dua perbedaan antara data yang didapatkan secara langsung dari masyarakat yang umumnya digunakan sebagai data primer dan data yang didapat dari bahan pustaka sebagai data sekunder (Soekanto \& Mamudji, 2006). Pada penelitian ini peneliti menggunakan data sekunder. Data sekunder terbagi atas bahan hukum primer, bahan hukum sekunder dan bahan hukum tersier. Dimaksud dengan bahan hukum primer adalah bahan hukum yang bersifat mengikat, yang terdiri dari norma atau kaidah dasar, peraturan dasar, peraturan perundang-undangan, bahan hukum yang tidak dikodifikasikan, yurisprudensi, traktat, dan bahan hukum dari zaman penjajahan yang hingga kini masih dinyatakan keberlakuannya. Dimaksud dengan bahan hukum sekunder adalah bahan yang memberikan penjelasan mengenai bahan hukum primer seperti RUU, hasilhasil penelitian, hasil karya dari kalangan umum dan lain- lain. Kemudian, dimaksud dengan bahan hukum tersier adalah berupa kamus, ensiklopedia, indeks kumulatif dan sejenisnya. Sumber hukum primer yang digunakan adalah UUD 1945, UU Nomor 5 Tahun 1986 tentang Peradilan Tata Usaha Negara, UU Nomor 9 Tahun 2004 tentang Perubahan Pertama Atas Undang-Undang Nomor 5 Tahun 1986 tentang Peradilan Tata Usaha Negara, UU Nomor 51 Tahun 2009 tentang Perubahan Kedua Atas Undang-Undang Nomor 5 Tahun 1986 tentang Peradilan Tata Usaha Negara, UU Nomor 30 Tahun 2014 tentang Administrasi Pemerintahan dan perundang-undangan dan putusan PTUN yang terkait dengan permasalahan yang dibahas.

Adapun beberapa teknik yang digunakan dalam pengumpulan bahan hukum serta teknik yang dipergunakan penulis dalam penulisan skripsi ini merupakan teknik sistem mencatat yaitu setelah mengumpulkan bahan yang diperlakukan selanjutnya dibuatkan catatan untuk hal-hal penting bagi penelitian terkait.

\section{HASIL DAN PEMBAHASAN}

\section{Pengaturan Keputusan Tata Usaha Negara Fiktif}

Definisi KTUN berdasarkan ketentuan Pasal 1 angka 9 UU Nomor 51 Tahun 2009 Perubahan Kedua Atas UU PTUN adalah sebagai berikut :

"Keputusan Tata Usaha Negara adalah suatu penetapan tertulis yang dikeluarkan oleh badan atau pejabat tata usaha negara yang berisi tindakan hukum tata usaha negara yang berdasarkan peraturan perundang-undangan yang berlaku, yang bersifat konkret, individual, dan final, yang menimbulkan akibat hukum bagi seseorang atau badan hukum perdata."

UU Nomor 30 Tahun 2014 Administrasi Pemerintahan memberikan istilah berbeda terkait KTUN yang disebut sebagai Keputusan Administrasi Pemerintahan. Administrasi Pemerintahan menyebutkan 
bahwa Keputusan Administrasi Pemerintahan juga disebut sebagai KTUN atau Keputusan Administrasi Negara. KTUN dapat menjadi objek sengketa TUN adalah suatu KTUN yang isi atau substansinya berbeda dengan asas umum pemerintah yang baik. Dalam hal ini KTUN yang dapat digugat meliputi KTUN Fiktif Negatif dan KTUN Fiktif Positif.

KTUN merupakan pokok dasar atau objek mutlak dari suatu sengketa tata usaha negara. Dengan diberlakukannya Undang-Undang Nomor 30 Tahun 2014 tentang Administrasi Pemerintahan, maka melalui undang-undang tersebut diberikan pula pengertian terkait Keputusan Tata Usaha Negara meskipun sebelumnya telah diatur melalui UU Nomor 51 Tahun 2009 Perubahan. Kedua Atas UU PTUN. Meskipun sama-sama memberikan pengertian tentang KTUN, namun terdapat beberapa perbedaan dari masing-masing pengertian yang diberikan oleh undang-undang tersebut.

Ketentuan tentang KTUN yang fiktif negatif tidak diatur secara tersurat dalam UU Nomor 30 Tahun 2014 Administrasi Pemerintahan. Dalam ketentuan Pasal 1 ayat (7) UU Administrasi Pemerintahan berisi tentang makna dari sikap diam badan atau pejabat TUN yang tidak memberikan respon terhadap permohonan yang diajukan orang/individu atau badan hukum perdata. Terhadap keberadaan Pasal 53 Undang-Undang Nomor 30 Tahun 2014 tentang Administrasi Pemerintahan memiliki penekanan waktu dari berlakunya. hal ini dilihat pada ketentuan Pasal 53 ayat (1) pada konteks "batas waktu" kepada badan atau pejabat TUN agar segera menetapkan keputusan.

Bertolak belakang dengan ketentuan Pasal 3 ayat (1) Undang-Undang Peradilan Tata Usaha Negara yang memberikan secara langsung pengertian terhadap Keputusan Tata Usaha Negara fiktif yang dikeluarkan pejabat TUN menolak permohonan baik diajukan oleh orang dan badan hukum perdata. Sehingga pemaknaan sebagai sebuah pengujian KTUN fiktif dari Pasal 53 dari UU Nomor 30 Tahun 2014 Administrasi Pemerintahan baru dapat terlihat ketika klausul "setelah permohonan diterima secara lengkap oleh Badan dan/atau Pejabat Pemerintahan" yang mana "permohonan" tersebut memberikan pengujian dari suatu Keputusan fiktif positif pada ketentuan pasal ini.

Berdasarkan pada ketentuan Pasal 3 UU PTUN yang mengartikan bahwa sikap diam dari badan atau pejabat TUN telah melanggar asas-asas umum pemerintahan yang baik (AAUPB) (Setiabudhi, 2014), karena sebagai badan atau pejabat TUN yang seharusnya dianggap memberikan pelayanan baik ke masyarakat justru bertindak sebaliknya. Secara fiktif haruslah dianggap keputusan penolakan ketika lewatnya hari terakhir dari tenggang waktu yang ditentukan (Ali Abdullah, 2015).

Dengan tidak menanggapi permohonan dan telah lewatnya jangka waktu yang diajukan, maka setelah itu baru dapat diajukan gugatan ke Pengadilan Tata Usaha Negara yang berwenang dengan tetap memperhatikan ketentuan Pasal 55 UU PTUN.

KTUN fiktif positif diatur dalam Pasal 53 UU Nomor 30 Tahun 2014 Administrasi Pemerintahan. KTUN fiktif positif merupakan kebalikan dari KTUN fiktif negatif. KTUN fiktif negatif mengartikan sikap diam badan atau pejabat TUN sebagai suatu keputusan penolakan dan terhadap KTUN fiktif positif, sikap diam dari badan atau pejabat tata usaha negara ini diartikan sebagai suatu pengabulan terhadap permohonan yang diajukan.

\section{Keputusan TUN Fiktif Sebagai Obyek Sengketa TUN}

Definisi Sengketa Tata Usaha Negara yang tertuang dalam Pasal 1 angka 10 UU Nomor 51 Tahun 2009 PTUN adalah:

"Sengketa Tata Usaha Negara adalah sengketa yang timbul dalam bidang tata usaha negara antara orang atau badan hukum perdata dengan badan atau pejabat tata usaha negara, baik di pusat maupun daerah, sebagai akibat dikeluarkannya keputusan tata usaha negara, termasuk sengketa kepegawaian berdasarkan peraturan perundang-undangan yang berlaku."

Berdasarkan ketentuan tersebut maka dapat dikatakan yang menjadi subyek sengketa tata usaha negara merupakan orang serta badan hukum perdata di satu pihak dan pejabat TUN di sisi lainnya. Sehingga diketahui bahwa para pihak yang terkait dalam di dalam sengketa TUN hanya orang atau badan hukum perdata dan pejabat TUN.

Keputusan TUN Fiktif sendiri digunakan sebagai obyek sengketa dikarenakan adanya disharmonisasi antara UU nomor 30 tahun 2014 Administrasi pemerintahan dan UU nomor 51 tahun 2009, perubahan kedua atas UU PTUN. Meskipun sama - sama memberikan pengertian tentang KTUN, namun terdapat perbedaan dari masing - masing pengertian yang diberikan oleh undang undang tersebut, sehingga membuat kerancuan atau ketidakpastian hukum terhadap putusan yang telah dikeluarkan sehingga dijadikanlah keputusan TUN fiktif sebagai obyek sengketa TUN. 
Prosedur penyelesaian sengketa dari gugatan maupun permohonan yang diajukan berdasarkan KTUN fiktif negatif atau KTUN fiktif positif memiliki beberapa perbedaan tersendiri baik dari segi dasar hukum pengaturannya, bentuk pengajuan ke pengadilan, tenggang waktu, tindakan yang dihasilkan, maupun hukum acara yang berlaku dalam proses penyelesaian sengketa tata usaha negara itu sendiri.

Dari segi dasar hukum yang mengatur pengajuan gugatan dengan Keputusan Tata Usaha Negara Fiktif Negatif sebagai objeknya diatur dalam ketentuan Pasal 53 UU PTUN. Di sisi lain, pengajuan permohonan dengan Keputusan Tata Usaha Negara Fiktif Positif sebagai objeknya diatur dalam ketentuan Pasal 53 Undang- Undang Nomor 30 Tahun 2014 tentang Administrasi Pemerintahan dan Peraturan Mahkamah Agung Nomor 5 Tahun 2015 tentang Pedoman Beracara Untuk Memperoleh Putusan Atas Penerimaan Permohonan Guna Mendapatkan Keputusan dan/atau Tindakan Badan atau Pejabat Pemerintahan.

Sebagaimana telah disebutkan di atas bahwa KTUN fiktif negatif dapat diajukan sebagai objek sengketa dalam bentuk gugatan namun KTUN fiktif positif dapat diajukan sebagai dasar atau objek sengketa dalam bentuk permohonan (Adiyasa, Tjukup, \& Martana, 2018). Tenggang waktu dari pengajuan gugatan (KTUN fiktif negatif) sesuai dengan ketentuan Pasal 3 ayat (2) dan (3) adalah setelah jangka waktu yang diberikan pada undang-undang berakhir atau 4 bulan apabila tidak diatur dalam undang-undang serta tetap berpedoman pada ketentuan Pasal 55 UU PTUN. Sedangkan untuk tenggang waktu pengajuan permohonan apabila tidak diatur dalam undang-undang maka dalam jangka waktu 10 (sepuluh) hari sejak diajukan permohonan, apabila telah lewat maka dapat diajukan permohonan ke pengadilan.

Sejatinya gugatan dan permohonan adalah dua peristilahan yang memiliki perbedaan tersendiri. Istilah gugatan pada umumnya lebih mengacu pada suatu sengketa yang nanti hasil akhirnya adalah berupa putusan, sedangkan permohonan lebih mengacu pada suatu hal yang dimohonkan secara voluntair dengan hasil akhirnya berupa penetapan. Namun dengan berlakunya ketentuan pasal 53 Undang-Undang Nomor 30 Tahun 2014 tentang Administrasi Pemerintahan yang mengatur terkait KTUN fiktif positif dan secara tidak langsung memunculkan Perma Nomor 5 Tahun 2015 tentang Pedoman Beracara Untuk Memperoleh Putusan Atas Penerimaan Permohonan Guna Mendapatkan Keputusan dan/atau Tindakan Badan atau Pejabat Pemerintahan maka muncul suatu pemaknaan baru tentang permohonan berdasarkan aturan tersebut. Pemaknaan permohonan dalam perma sebagaimana dimaksud mengarah pada suatu permohonan dalam bentuk sengketa antara para pihak baik itu pemohon (orang/individu atau badan hukum perdata) melawan termohon (badan atau pejabat administrasi pemerintahan). Kendati demikian, baik gugatan maupun permohonan yang diajukan masih melewati proses yang sama dalam hal penyelesaian perkaranya bahkan hasil akhir dari kedua istilah yang berbeda ini adalah berupa Putusan. Sehingga memang terdapat suatu ketimpangan dalam penggunaan istilah permohonan sebagai bentuk pengajuan KTUN fiktif positif ke Pengadilan Tata Usaha Negara.

\section{SIMPULAN DAN SARAN}

\section{Simpulan}

Pengaturan keputusan TUN fiktif dibagi menjadi 2 yaitu TUN fiktif negatif dan TUN fiktif positif. Kedua aturan tersebut secara tidak langsung menimbulkan konflik dikarenakan sama-sama mengatur tentang sikap diam dari badan atau pejabat tata usaha negara namun memiliki pemaknaan yang berbeda, dimana berdasarkan ketentuan Pasal 3 dimaknai sebagai keputusan penolakan atau KTUN Fiktif Negatif sedangkan sikap diam menurut ketentuan Pasal 53 dimaknai sebagai keputusan pengabulan atau KTUN Fiktif Positif.

Kemudian, keputusan TUN fiktif sebagai obyek sengketa TUN saat ini di Indonesia masih banyak yang tidak mendapat ketidakpastian hukum dan tentunya akan membawa kerugian tersendiri bagi penggugat yang mendalilkan KTUN fiktif dalam konstruksi gugatanya. Kerugian yang dialami oleh penggugat tidak hanya kerugian materiil saja tapi juga merugi secara moril dikarenakan adanya harapan atas keberlakuan pasal 3 UU PTUN.

\section{Saran}

Melalui penelitian ini diharapakan dalam penyelenggaraan negara yang baik tentunya dibutuhkan suatu kepastian hukum untuk menjamin adanya keadilan dan ketertiban yang tercipta dalam negara itu sendiri. 
Masih berlakunya kedua ketentuan yang mengatur tentang sikap diam badan atau pejabat tata usaha negara dengan pemaknaan berbeda akan menimbulkan ketidakpastian hukum dalam penerapannya. Untuk itu penulis menyarankan kepada lembaga yang berwenang untuk mencabut ketentuan Pasal 3 UU PTUN sehingga akan tercipta kepastian hukum dengan adanya satu ketentuan yang mengatur tentang sikap diam badan atau pejabat tata usaha negara. Sehingga apabila orang/individu atau badan hukum perdata ingin mengajukan gugatan maka dapat mendalilkan KTUN Fiktif Positif sebagai objek sengketanya. Selanjutnya, penggunaan istilah permohonan dalam pengajuan untuk mendapat Keputusan Pengabulan sebagaimana tertuang dalam Perma Nomor 5 Tahun 2015 sekiranya kurang tepat mengingat pemaknaan dari permohonan bukanlah untuk perkara yang mengandung sengketa, sehingga penulis menyarankan akan lebih tepat apabila digunakan istilah gugatan sebagai pengajuan untuk mendapat Keputusan Pengabulan melalui Pengadilan Tata Usaha Negara. Sehingga dalam hal ini tidak menutup kemungkinan untuk dibuatkan ketentuan pasal baru yang lebih menitik pada KTUN Fiktif sebagai objek sengketa tata usaha negara dan diajukan melalui gugatan.

\section{DAFTAR PUSTAKA}

Adiyasa, I. P. A. P., Tjukup, I. K., \& Martana, N. A. (2018). Sikap Diam Badan atau Pejabat Pemerintahan Sebagai Objek Gugatan Sengketa Tata Usaha Negara. Kertha Wicara, 07(03).

Ahmad. (2017). Konsep Fiktif Positif: Penerapannya di Pengadilan Tata Usaha Negara. Jurnal Hukum Replik, $5(2), 141$.

Ali Abdullah. (2015). Teori dan Praktik Hukum Acara Peradilan Tata Usaha Negara Pasca-Amandemen.

Daliyo, J. B. (1989). Pengantar Ilmu Hukum. Jakarta: Gramedia.

Dirdjosisworo, S. (2010). Pengantar Ilmu Hukum. Jakarta: PT. Raja Grafindo Persada.

Heriyanto, B. (2019). Problematika Penyelesaian Perkara "Fiktif Positif" Di Pengadilan Tata Usaha Negara. Pakuan Law Review, 5(1), 38-56.

Marzuki, P. M. (2010). Penelitian Hukum (VI). Jakarta: Predana Media Group.

Setiabudhi, D. O. (2014). Keputusan Fiktif Negatif sebagai Dasar Pengajuan Gugatan Dalam Sengketa Tata Usaha Negara Yang Berkaitan Dengan Pelayanan Dalam Bidang Pertanahan (Manado).

Soekanto, S., \& Mamudji, S. (2006). Penelitian Hukum Normatif: Suatu Tinjauan Singkat. Jakarta: PT Raja Grafindo Persada.

Wulandari, D. (2020). Pengujian Keputusan Fiktif Positif Di Pengadilan Tata Usaha Negara. Jurnal Lex Renaissance, 5(1), 32-56. 